\section{Multidisciplinary Working Process of the Psychosocial Care Centers in the Extended Clinic Context}

\section{Abstract}

Objective: To discuss the importance of multidisciplinary care for patients with mental distress based on the context of the extended clinic.

Method: This is a theoretical essay.

Results: The WHO and the Pan-American Health Organization (PAHO) state that $12 \%$ of global diseases come from mental disorders. In this context, seek the understanding of the organization of CAPS of the multidisciplinary team working process is an important reflection for (re) construction of mental health practices in the territory. From this perspective, the work process seeks to overcome the Cartesian, biological and reductionist conception of the health-disease process, which ignores the subjectivity and strongly present symbolisms in substitutive services to psychiatric hospitals.

Conclusion: This trial helps the discussion about care in expanded clinic perspective in the routine of CAPS. Thus, the expanded clinic production through the organization of the multidisciplinary team working process in CAPS is feasible, and it is important for the implementation of a mental health policy to reduce inequalities and contribute to the strengthening of the patient's quality of life in mental distress.
Yanna Gomes de Sousa1, Soraya Maria de Medeiros ${ }^{2}$, Bertha Cruz Enders², Ana Elisa Pereira Chaves ${ }^{3}$, Marília Souto de Araújo 4

1 Nurse. Master degree student of the Graduate Program in Nursing, Federal University of Rio Grande do Norte/ UFRN. Natal (RN), Brazil.

2 Nurse, Ph.D. Professor, Graduate Program in Nursing of the Department of Nursing at UFRN/Natal (RN) Brazil.

3 Nurse. Master. Ph. D. student in the Graduate Program in Nursing, Federal University of Rio Grande do Norte/ UFRN. Natal (RN), Brazil.

4 Student in Graduate in Nursing, Federal University of Rio Grande do Norte/ UFRN. Natal (RN), Brazil.

Contact information:

Yanna Gomes de Sousa.

” yanna_gomes@yahoo.com.br

\section{Keywords}

Psychiatric Nursing;

Mental Health; Work Process;

Clinical Extended.

\title{
Introduction
}

According to the International Classification of Mental and Behavioral Disorders (ICD-10) [1], mental disorders (MD) are classified as a disease with psychological manifestation associated with any functional impairment from biological, social, psychological, genetic, 
physical or chemistry dysfunction. They are also classified as changes in the way of thinking and/ or mood associated with significant distress, producing losses in the overall performance of the person in the personal, social, occupational and family aspects [2].

Mental disorders were not recognized as a serious public health problem from 1996, when researchers at Harvard University and the World Health Organization (WHO) published a study [3] with the 10 main causes of disability worldwide and five of them were associated with the MD, including the depression (13\%) and alcohol intake (7.1\%), bipolar affective disorders (3.3\%), schizophrenia (4\%) and obsessive -compulsive disorders (2.8\%).

The WHO and the Pan-American Health Organization (PAHO) [4] report that Mental Disorders were $12 \%$ of global diseases and $1 \%$ of mortality while less than $1 \%$ of health resources are invested in actions for mental health. Nevertheless, more than $40 \%$ of countries still lack in mental health policies, and $30 \%$ have no programs in this area.

It is also known that most mental disorders are treatable and preventable, corroborating the assumption that, when investing in prevention and promotion of mental health, the number of disabilities from the psychiatric disorders can greatly reduce.

In Brazil, the psychiatric reform is a reality that has brought reactions and attention of society. It has emerged as an ongoing effort to bring about social change in dealing with madness and understand it as a phenomenon of life.

Formulated as a public policy of the state, the psychiatric reform in Brazil is supported by Law $10,216 / 2001$ and by several elaborated and implemented ordinances by the Ministry of Health that through the mental health policy, it aims to produce a health care quality and to respect the principles of universality and equity to contribute to the construction of autonomy and citizenship of individuals.
In this sense, the psychiatric reform is an intense movement that does not end, because it seeks the progressive dismantling of psychiatric thought facing repression, which is the result of a Cartesian, reductionist view, which segregates the subjects and prevents their growth, preventing symbolic exchanges between individuals and professionals. [5]

After the movement of the psychiatric reform, new ways addressing psychological distress were built with foundations in the proposal of a multidisciplinary work, seeking to recast the old service format that was strictly hospital-centered based. In this scenario, the struggle for autonomy and citizenship of the "crazy man" is the main topic of the reform, giving a political character to this movement. [6]

Thus, the Psychosocial Care Centers (CAPS), created and regulated by Ordinance 336/GM of February 19, 2002, by the Ministry of Health, effectively emerge in Brazil reaches today 2,155 units across the country with 1,035 Psychosocial Care Centers I, 475 Psychosocial Care Centers II, 82 Psychosocial Care Centers III, 196 Psychosocial Children and Youth Care Centers, 308 Alcohol and Other Drugs Psychosocial Care Centers -CAPS-AD and 59 Psychosocial Care Centers-AD III 24 hours. [7]

Psychosocial Care Centers (CAPS) are an open health and community service of the Unified Health System (SUS). It is a place of reference and treatment for people suffering from mental disorders, psychosis, severe neurosis and other conditions, whose severity and/or persistence justify their stay in an intensive care unit, community, and personal lives promoter. [8]

The psychosocial care field is marked by different guidelines. Those from the Italian democratic psychiatry, which emphasize the political dimension and propose a suppression of clinical for care to the clinical returners, incorporating the psychosocial care procedures, going to designate it as an extended clinic as a clinic of the subject, in 
which there is the presence of the psychoanalytic discourse. [6]

The organization of the work process of professionals who are in CAPS is closely linked to how to (re) produce health holistically since this service takes the central element position in the network of the mental and psychiatric health. Moreover, the main relational care technologies used in this type of service are the light and light-hard technologies, highlighting the bond and the host as the main working tools.

In the meantime, all mental health service with its organization directed to the needs of the individual result in the production of health and life in different social territories. This is considered essential to compose a comprehensive proposal in the context of policies and health practices. [9]

From the understanding of this work organization process considering the unique needs of the individual, this theoretical essay aims to emphasize the importance of reflecting on the process of organizing the work of the multidisciplinary CAPS team and (re) think the implementation of health practices that promote a better quality of life of users assisted by substitutive mental health services.

It is important to seek the understanding of the organization of the work process in CAPS, understanding it as a producer of reflection, from the development of mental health practices in the territory and its main perspectives in the way of acting and producing mental health.

The approach in the context of extended clinic goes beyond care guided by techniques and protocols. It assumes the shared comprehensive care with a tendency to interdisciplinary relationships horizontally, capable of patients and family members to be autonomous and have efficient self-assistance.

\section{Method}

This theoretical essay discusses the care of the multidisciplinary team of the Psychosocial Care Centers-
CAPS, its prospects and the influence of prevailing paradigms and emerging with a focus on care in the context of the extended clinic from the look of different authors.

A literature search was performed in electronic databases (Latin American and Caribbean Health Sciences (Lilacs), Scientific Electronic Library Online (SciELO), National Library of Medicine (PubMed) and SCOPUS) and books.

\section{Results}

The results were divided into three areas, the first one deals with the concepts inherent in psychiatric reform, the second deals with the development of the clinic at the Psychosocial Care Center and the third, it is the organization of the multidisciplinary team working process towards the construction of the extended clinic as a care technology in mental health.

\section{Psychiatric reform}

Psychiatry was born in the eighteenth century when it emerged capitalism on the world stage. In this period, the "madness" was considered a magicalreligious phenomenon that has been moved to the medicine and modern science field, thus, the subjects that make up the current Psychiatry [10].

In Brazil, the "madness" has become the subject of a specific intervention by the State from the arrival of the Royal Family in the early nineteenth century. This moment followed social and economic changes in the country, requiring efficient measures of social control that without them, it would be impossible to put in order the growth of cities and populations [7]

With the numerous transactions that occurred within the Brazilian mental health, the first CAPS opened in the country in March 1986 in São Paulo. The creation of CAPS was part of an intense social movement, which sought to improve care in Brazil and denounced the precarious situation of psychia- 
tric hospitals, which was the only resource intended for users with mental disorders [6].

It is noteworthy that the service promoted by CAPS use the bond, host, active listening and understanding tools of the bio-psycho-socio-cultural users in mental distress, believing that the user has great ability to change about life and mental illness promoting the practice of institutionalization and citizen user assistance [11]

The psychosocial care developed in the CAPS suggests the prospect of paradigm transforming the psychiatric reform since it implies innovation of a new model of care for mental suffering based on principles and values that enable to reinvent the society so that there is a space for the crazy subject.

In this context, the Psychiatric Reform seeks a transformation of practices, knowledge, cultural and social values. Moreover, in the routine of the institutions, services, and interpersonal relationships, the process of Psychiatric Reform advances marked by impasses, tensions, conflicts and challenges [12]

\section{Clinical Development in the Psychosocial Care Center-CAPS}

When considering the clinic developed in CAPS as an object of reflection, we emphasize the importance of medical knowledge at the origin of the idea of the clinic.

In the life of the modern man, the medical discourse occupies a key place, based on science and health promises as a way to salvation, though, recognizing the inevitable death. The disease is addressed in an objective, dissociated form of the existence of the subject as a set of symptoms, and signs to be deciphered by medical knowledge [13]

The term "clinic" comes from the Greek Kline term, that is, "bed", which doctors extracted the individual act of the patient "leaning over the bed", seeking a closer relationship between the scientist and the studied phenomenon. This clinic dominates a knowledge legitimized by the scientism of human nature, giving the man an ideal and healthy state as he should be and being in the world. If maybe, there is any deviation from the idealized "natural" state, as the human being must be, the subject will be placed before the clinical look of medicalization, as the only form capable of (re) lead him to the most imperative normality [14]

In the development of care practices by the expanded clinic, the practices developed in CAPS are not confused with the psychiatric clinic, focused on the treatment of the disorder in the psychiatric hospital.

In the current reality, the psychosocial care procedures incorporate the dimension of the subject and the CAPS being a service to replace hospitalizations, becoming the main strategy of the psychiatric reform, as well as the mental health network in Brazil, which the multidisciplinary team admits users referred by the Family Health Strategy (FHS) and spontaneous demand.

In the health field, a multidisciplinary team is a team that works together with different areas of professionals with a common goal, the restructuring of the work process in health services to changes in ways of acting on the health-disease process [15]. This proposal was adopted as a coping strategy of hyper-specialization and fragmentation of the care process, reflecting vertical and rigid aspects without considering the individual needs [16]

Regarding the multidisciplinary team in CAPS, its medical care to patients with mental disorders in Brazil over the years has been developing and seeking to meet the proposals from the Psychiatric Reform, where professionals need a contrary practice started with traditional psychiatry, characterized by isolation and the punitive treatment, aimed at the physical and chemical containment of these customers [17].

Despite this progress, the performance space in CAPS is not given, and it must be earned. Thus, this horizon that appears in the mental health field is constructed/deconstructed from inter-subjective 
communication established between all social actors and multidisciplinary team involved in the mental healthcare, from dialogues and changes being part of the way to work, becoming the effective field of nursing therapeutic action.

It is important to point out that the therapeutic action developed in CAPS should seek to provide a care, not with the connotation of duty and obligation, but that allows the redemption of stories of each user-assisted, participating in the (re) construction of citizenship and the right of living, trying to fulfill dreams and desires that were asleep in the chemical and social contentions of psychiatric hospitals.

\section{Organization of the multidisciplinary team working process towards the construction of the extended clinic: An assistive technology in mental health}

The proposal of de-institutionalization of the model centered on the psychiatric hospital is one of the strongest theoretical references of mental health policy and has resonance in society due to economic, emotional and ideological aspects, which produce the place of segregation established technical, social and culturally to "madness."

In this process, there is the acquisition of new knowledge and ways of acting in health, to adapting workers to new services and the mental health network. Also, the occurrence of an inversion in the organizational logic of the work process before guided by hierarchical rigidity, individualized activity and separation of worker/product, worker/meaning and object of work, through developing a work team in interdisciplinary and horizontal dynamics, which strives for collective construction work processes [17]

Opposite to the asylum model, where there is the social isolation of users, a new care paradigm emerged, guided by psychosocial care, in which inclusion and rehabilitation are the central axes. In this context, the health team performs individual and collective assistance with direct and indirect interventions. Many of these activities were already part of the work process in the asylum model, and this new way is re meant to respond to the complexity of mental illness.

The multidisciplinary team working process should be articulated and delineated, so there are possibilities of construction of a caring space that promotes structural changes in the labor process, creating reciprocity, mutual enrichment of practice and horizontality of power relationships between the different knowledge fields.

The methodology that organizes this work process is directly related to the use of soft technology and the ability to deal with the biological, social and psychological aspects, where the psychological aspect is linked intrinsically to the uniqueness and subjectivity of service users.

The main perspectives in the way of acting of the mental health team come in daily work, when they develop their assignments with a focus on work organization on individual/subjective and collective/ service demands in therapeutic workshop group, envisioning the construction of the expanded clinic.

However, it is essential to understand that this form of organization of the production process and, consequently, the mental health care do not have a definite and concrete way to prioritize work process in services causing a movement of change for the clinical and political paradigm to articulate the encounter between subject and rebuilding of lives lost stories.

The knowledge and practice that make up mental health care are thought and made effective in the context of expanded clinic. The expanded clinic does not devalue any approach. It seeks to integrate various topics to enable effective management of the complexity of health work. Thus, it is tried not focus only on the intervention of clinical practice on illness and also prioritize work aimed at valuing the uniqueness of each subject [18].

The expanded clinic proposes that health professionals develop the ability to help people, not only to fight the disease but to transform, so the disease, 
even though a limit, it does not prevent them from living other things in their lives [19]

In this way, it seeks the uniqueness of the subject, seeking the production of health, rehabilitation and expansion of autonomy, by building links, integration of the multidisciplinary team, expansion of intervention resources in the health-disease.

The expanded clinic concept aims to involve aspects related to illness beyond the biological, combining therapeutic approaches discussed by a multidisciplinary team, through Singular Therapeutic Project (STP). STP assumes a deepening of the discussion of the problem, actions, and involvement of the various parts of the process as the involvement of family and team resources and territory, as well as the user [20].

In this perspective, it is expected that the worker takes a critical and informed stance on mental health, boosting the adoption of strategies for carrying out actions based on new ways to watch and practice care. These actions should be combined with users and community to promote good physical, mental and social subjects.

According to the above, it is considered that the organization of the work process in CAPS becomes an essential element in the production of expanded clinic on that service. This is feasible to implement a mental health policy that overcomes the Cartesian, biological and reductionist conception developed by the psychiatric hospital.

Also, the health practices developed in the context of the expanded clinic make the environment permeated with creativity, care, interdisciplinary, active listening and sharing of knowledge that empowers the individual seeking the production of their autonomy and uniqueness.

Therefore, it is proposed the construction of a prepared and available environment to accommodate the demand for the mental health and offer a listening and extended care. The construction of the expanded clinic will give the opportunity to the individual to be placed as a major protagonist in his history, engaging him in the promotion of his health process, expanding and discovering what is beyond his clinical psychiatric diagnosis from new subjective formations, different from those that possibly led to the mental illness.

\section{References}

1. Organização Mundial da Saúde. Classificação de TM e de comportamento da CID-10. Porto Alegre: Artes Médicas; 1993.

2. Santos Élem Guimarães dos, Siqueira Marluce Miguel de. Prevalência dos transtornos mentais na população adulta brasileira: uma revisão sistemática de 1997 a 2009. J. bras. psiquiatr. [Internet]. 2010 [cited 2016 Mar 21]; 59(3): 238-246.

3. Organização Pan-Americana de Saúde. Organização Mundial da Saúde. Relatório sobre a saúde no mundo 2001. Saúde Mental: nova concepção, nova esperança. OMS; 2001.

4. World Health Organization. Cross-national comparisons of the prevalences and correlates of mental disorders. Bulletin WHO. 2000; 78(4):413-26

5. Pinho LB, Kantorski LP, Wetzel C, Schwartz E, Lange C, Zillmer JGV. Avaliação qualitativa do processo de trabalho em um centro de atenção psicossocial no Brasil. Rev Panam Salud Publica. 2011: 30(4):354-60.

6. Rinaldi, DL, Bursztyn DC. O desafio da clínica na atenção psicossocial. Arquivos Brasileiros de Psicologia [online]. 2008a, v. 60, n.2 Rio de Janeiro.

7. Ministério da Saúde. Secretaria de Atenção à Saúde. Departamento Área Técnica de Saúde Mental do Ministério da Saúde - Brasília: Ministério da Saúde, 2015. Disponível em: http://www.brasil.gov.br/observatoriocrack/cuidado/outroscentros-atencao psicossocial.html. Acesso em: 02 de junho de 2015.

8. Ministério da Saúde. Secretaria de Atenção à Saúde. Departamento de Ações Programáticas Estratégicas. Saúde mental no SUS: os centros de atenção psicossocial/Ministério da Saúde, Secretaria de Atenção à Saúde, Departamento de Ações Programáticas Estratégicas. Brasília: Ministério da Saúde, 2004.

9. Merhy EE. Em busca do tempo perdido: a micropolítica do trabalho vivo em saúde. Merhy EE, Onocko R, orgs. Agir em saúde: um desafio para o público. 2nd ed. São Paulo: Hucitec; 2006:71-112

10. Foucault M. (1987) A História da Loucura na Idade Clássica. 2a ed. São Paulo: Ed. Perspectiva.

11. Brasil. Ministério da Saúde. Portaria GM n³36, de 19 de fevereiro de 2002. Define e estabelece diretrizes para o funcionamento dos Centros de Atenção Psicossocial. Diário Oficial da União 2002. 
12. Ministério da Saúde. Secretaria de Atenção à Saúde. DAPE. Coordenação Geral de Saúde Mental. Reforma psiquiátrica e política de saúde mental no Brasil. Documento apresentado à Conferência Regional de Reforma dos Serviços de Saúde Mental: 15 anos depois de Caracas. OPAS. Brasília, novembro de 2005

13. Nascimento $Y C M L$, Brêda $M Z$, Albuquerque MCS. Mental illness: perceptions regarding sufferers' identities. Interface (Botucatu). 2015; 19(54):479-90

14. Foucault M. O nascimento da Clínica, $6^{a}$ ed., São Paulo: Ed. Forense Universitária, 2004

15. Costa RKS, Enders BC, Menezes RMP. Trabalho em equipe de saúde: uma análise contextual. CiencCuidSaude. 2008; 7(4): 530-6

16. Peduzzi, M. Equipe multiprofissional de saúde: conceito e tipologia. Rev Saúde Pública, 2001; 35(1): 103-9

17. Sampaio JJC, Guimaraes JMX, Carneiro C, Carlos GF. O trabalho em serviços de saúde mental no contexto da reforma psiquiátrica: um desafio técnico, político e ético. Ciênc. saúde coletiva [online]. 2011, vol.16, n.12, pp. 4685-4694. ISSN 14138123. http://dx.doi.org/10.1590/S1413-81232011001300017.

18. Ministério da Saúde. Clínica Ampliada, Equipe de Referência e Projeto Terapêutico Singular/Ministério da Saúde, Politica Nacional de Humanização. 2.ed. Brasília: Ministério da Saúde, 2007.

19. Onocko-Campos R, Gama CA. Saúde Mental e saúde coletiva. In: CAMPOS, Gastão Wagner de Sousa et al. (Org). Tratado de saúde coletiva. São Paulo: Hucitec; Rio de Janeiro: Fiocruz, 2006

20. Universidade Federal de Santa Catarina. Centro de Ciências da Saúde. Curso de Especialização Multiprofissional em Saúde da Família. Projeto terapêutico singular [Recurso eletrônico]/ Universidade Federal de Santa Catarina; Fernanda Alves Carvalho de Miranda; Elza Berger Salema Coelho; Carmem LeontinaOjeda O campo Moré. Florianópolis: Universidade Federal de Santa Catarina, 2012

Publish in International Archives of Medicine

International Archives of Medicine is an open access journal publishing articles encompassing all aspects of medical science and clinical practice. IAM is considered a megajournal with independent sections on all areas of medicine. IAM is a really international journal with authors and board members from all around the world. The journal is widely indexed and classified Q1 in category Medicine. 